\title{
EFEKTIFITAS KERJASAMA LUAR NEGERI BAGI PEMDA DI INDONESIA (KASUS KERJASAMA KELAUTAN DAN PERIKANAN PEMDA JABAR DENGAN PEMDA CHOLANAMDO)
}

\author{
Luerdi \\ Mahasiswa Pascasarjana Ilmu Politik Universitas Riau
}

\section{Citation as}

Luerdi, L. (2014). Efektifitas Kerjasama Luar Negeri bagi Pemda di Indonesia (Kasus Kerjasama Kelautan dan Perikanan Pemda Jabar dengan Pemda Cholanamdo). https://doi.org/10.31219/osf.io/tfjhr 


\title{
EFEKTIFITAS KERJASAMA LUAR NEGERI BAGI PEMDA DI INDONESIA (KASUS KERJASAMA KELAUTAN DAN PERIKANAN PEMDA JABAR DENGAN PEMDA CHOLANAMDO)
}

\author{
Luerdi \\ Mahasiswa Pascasarjana Ilmu Politik Universitas Riau
}

\section{Kerjasama Luar Negeri di Era Otonomi Daerah}

Otonomi daerah di Indonesia telah memberikan wewenang yang lebih besar kepada pemerintah daerah (pemda) untuk mengelola potensi daerahnya sendiri termasuk dalam hal kerjasama luar negeri. Dengan demikian, pemerintah pusat tidak lagi menjadi aktor yang merepresentasikan negara dalam menjalin hubungan luar negeri dengan pihak asing. UndangUndang (UU) No.32 tahun 2004 tentang otonomi daerah merupakan landasan hukum yang mengizinkan pemda menginisiasi dan menjalin kerjasama luar negeri namun tetap berada dalam kerangka kedaulatan NKRI (Luerdi, 2014). Berdasarkan ketentuan dalam UU tersebut, pemda harus melewati berbagai prosedur dan harus berkoordinasi dengan dan mendapatkan persetujuan dari pemerintah pusat. Sedangkan kerjasama di bidang politik luar negeri, pertahanan, kemananan, yustisi, moneter dan fiskal nasional, dan agama tetap menjadi wewenang pemerintah pusat (Kementerian Luar Negeri Republik Indonesia, 2012).

Seluruh pemda di Indonesia seharusnya dapat memberdayakan seluruh potensi yang ada di daerahnya baik itu sumber daya alam maupun sumber daya manusia salah satunya dengan cara menjalin Kerjasama luar negeri. Distribusi kewenangan yang diberikan kepada pemda menjadi alasan utama untuk memanfaatkan peluang tersebut. Beberapa kasus kerjasama luar negeri yang dilakukan oleh pemda-pemda di Indonesia menunjukkan berbagai manfaat yang diperoleh oleh daerah-daerah yang bersangkutan seperti alih teknologi, peningkatan kualitas sumber daya manusia, pendidikan dan perekonomian masyarakat setempat, dan percepatan pembangunan.

Namun dalam pelaksanaannya, tingkat efektifitas kerjasama yang dilakukan oleh pemda sangat beragam. Beberapa kasus menunjukkan pemda-pemda relatif berhasil dalam mendapatkan tujuan-tujuan yang telah direncanakan dari adanya kerjasama luar negeri tersebut. Sebaliknya, banyak pula pemda yang tidak dapat menindaklanjuti langkah-langkah awal yang telah dilakukan 
seperti penjajakan ke daerah di luar negeri ataupun mengimplementasikan berbagai kesepakatan atau MoU yang telah ditandatangani.

Tulisan ini berupaya menganalisis efektifitas kerjasama luar negeri yang dilakukan oleh pemda Jawa Barat (Jabar). Jabar termasuk salah satu propinsi yang giat melakukan kerjasama dengan pihak asing. Adapun kerjasama yang dilakukan oleh pemda Jabar yang dibahas adalah kerjasama kelautan dan perikanan dengan pemda Cholanamdo (Republik Korea).

\section{Kerjasama Pemda Jabar dengan Pemda Cholanamdo}

Bagi pemda Jabar, kerjasama dalam bidang kelautan dan perikanan dengan pemda propinsi Cholanamdo memiliki nilai strategis dan perlu untuk dilakukan. Selain karena Republik Korea merupakan negara maju dengan kemampuan ekonomi dan teknologi yang dapat dimanfaatkan melalui kegiatan kerjasama, pemda Cholanamdo juga tertarik untuk melakukan kerjasama dengan pemda Jabar. Propinsi Cholanamdo bukanlah pihak asing pertama dan satu-satunya dari Republik Korea yang telah menjalin kerjasama dengan propinsi Jabar. Beberapa kerjasama sister province sebelumnya antara Jabar dan propinsi-propinsi lain dari Republik Korea membantu memberikan mutual trust bagi kedua belah pihak.

Pemda Jabar menyadari bahwa wilayah lautnya memiliki potensi sumber daya perikanan yang besar. Namun belum optimalnya ekspoitasi perairan oleh masyarakat khususnya para nelayan, terbatasnya kemampuan nelayan dan teknologi yang digunakan untuk mengotimalkan hasil tangkapan ikan, serta belum meratanya tingkat kesejahteraan para nelayan menjadi alasan bagi pemda jabar melakukan kerjasama dengan pemda Cholanamdo. Selain itu keinginan untuk meningkatkan pengetahuan dan manajemen pengelolaan perairan bagi aparatur pemda Jabar juga menjadi tujuan lain dari pemda Jabar dalam kerjasama tersebut.

\section{Efektifitas Kerjasama bagi Pemda Jabar}

Stoner (dalam Windiani, 2011) menekankan pentingnya efektivitas organisasi dalam pencapaian tujuan-tujuan organisasi, dan efektivitas adalah kunci kesuksesan dari suatu organisasi. Efektifitas dapat diartikan sebagai sejauh mana suatu organisasi dalam hal ini pemda mampu mendapatkan tujuan-tujuan yang ingin dicapai. Selain itu, efektifitas berhubungan dengan kemampuan pihak tersebut melaksanakan kegiatan atau fungsinya agar tujuan-tujuan tersebut dapat dicapai (Windiani, 2011). Dalam hal ini, efektifitas yang dimaksud adalah sejauh mana 
pemda Jabar mampu melaksanakan kegiatan kerjasama yang telah direncanakan dan disepakati guna mencapai tujuan-tujuannya.

Adapun beberapa hal yang dapat menjadi aspek penilaian apakah kerjasama antara suatu pemda dalam negeri dengan pihak asing dikatakan efektif diantaranya adalah aspek legalisasi, sistem, institusionalisasi kerjasama, peranan kementerian, sosialisasi, dan manfaat kerjasama.

\section{Legalitas}

Indikator penting dari aspek legalitas adalah adanya Momarandum of Understanding (Mou) antara pihak-pihak yang terlibat kerjasama. MoU yang telah disetujui merupakan tanda bahwa suatu kerjasama dapat mulai memasuki tahap teknis implementasi. Kebanyakan MoU hanya memuat poinpoin kesepakatan secara umum sehingga dapat diperluas atau dipersempit bila dianggap perlu dan tentunya kedua pihak sama-sama sepakat dalam hal tersebut. Kebanyakan MoU juga tidak memuat ketentuan-ketentuan yang mengikat kedua belah pihak karena kerjasama dilakukan atas dasar suka rela. Walau demikian, suatu kerjasama dapat berjalan secara efektif dengan adanya mutual trust dari kedua belah pihak.

Dalam kerjasama antara pemda Jabar dengan pemda Cholanamdo, kedua belah pihak sepakat untuk menandatangi MoU sebagai wujud komitmen melakukan kerjasama. Dalam praktiknya pemda Cholanamdo bersedia untuk memberikan program bantuan pengadaan armada penangkapan ikan sebesar 15 milyar kepada para nelayan di Jawa Barat (Thontowi, 2009). Pemda

Cholanamdo juga memberikan bantuan-bantuan teknis lainnya, mengirim fasilitator dari Cholanamdo, dan melakukan saling tukar delegasi antar kedua propinsi.

\section{Sistem}

Dalam aturan yang berlaku di Indonesia, kerjasama yang dilakukan oleh pemda harus mengikuti prosedur yang legal dan tidak mendahului kewenangan pemerintah pusat. Pemda harus melakukan koordinasi dan sinergi dengan DPRD setempat, kementerian luar negeri dan kementerian lainya yang terkait. Pemda Jabar nampaknya telah melakukan alur ini dengan adanya MoU kerjasama dan persetujuan DPRD atas MoU tersebut melalui Keputusan DPRD Propinsi Jabar No.193/Kep-DPRD 44/2000. Pemda Jabar telah melakukan koordinasi yang baik dengan pemerintah pusat melalui kementerian yang ditandai dengan penerbitan full powers atau surat kuasa menteri luar negeri pada tanggal 15 Januari 2001 (Thontowi, 2009). 
Dari penjelasan di atas, pemda Jabar tidak mengalami masalah dengan sistem yang ada. Pemda Jabar telah menjalani alur dari sistem yang ada dimulai dari dari penerbitan Letter of Intent, persetujuan MoU, sampai pada penerbitan full powers.

\section{Institusionalisasi Kerjasama}

Efektifitas suatu kerjasama dapat dinilai dari aspek perorganisasian yang meliputi penunjukkan pihak yang bertanggungjawab sebagai leading sector dan pembentukan tim atau panitia untuk menangani kerjasama tersebut, termasuk pembentukan sekretariat kerjasama bila diperlukan. Untuk menangani kerjasama kelautan dan perikanan dengan pemda Cholanamdo, secara teknis pemda Jabar menyerahkan kerjasama ini pada biro sarana dan ekonomi (sarek) sekda pemda Jabar yang kemudian membentuk tim adhoc untuk menindak-lanjuti kerjasama tersebut (Thontowi, 2009).

\section{Peranan Kementerian}

Pemda tidak akan mampu melaksanakan suatu kerjasama luar negeri tanpa dukungan pemerintah pusat melalui kementerian terkait karena pemda memiliki keterbatasan wewenang. Dalam kerjasama yang dilakukan oleh pemda Jabar tersebut, kementerian kelautan dan perikanan setidaknya memberikan pertimbangan dan melengkapi data terkait potensi kelautan dan perikanan yang dimiliki oleh Jabar selain adanya data dari dinas pemda Jabar terkait.

Kementerian luar negeri berperan dalam membantu meyebarkan country profile khususnya propinsi Jabar dan mengfasilitasi komunikasi antara pemda Jabar dan pemda Cholanamdo sampai akhirnya terwujudnya kesepakatan antara kedua propinsi tersebut. Peranan paling penting dari kementerian luar negeri adalah penerbitan full powers untuk pemda Jabar atas rekomentasi kementerian sekretaris negara yang berarti pemda Jabar diberikan kewenangan penuh untuk mengelola kerjasama tersebut secara teknis implementasinya (Thontowi, 2009). Selain itu, kementerian sekretaris negara juga berperan dalam mempersiapkan draft MoU atau menilai usulan butir-butir dalam draft MoU yang diberikan oleh pemda Jabar.

\section{Sosialisasi dan Manfaat bagi Masyarakat}

Secara umum sosialisasi yang dilakukan oleh pemda Jabar efektif. Pemda Jabar melakukan sosialisasi kepada pihak-pihak terkait di lingkungannya untuk menyukseskan kerjasama dengan 
pemda Cholanamdo tersebut. Terlaksananya kerjasama tersebut juga tidak lepas dari sosialisasi yang dilakukan pemda Jabar kepada kelompok-kelompok nelayan yang menjadi sasaran objek kerjasama.

Lazimnya kerjasama luar negeri antara pemda dalam negeri dan pemda luar negeri sering membuka peluang terjadinya alih teknologi. Begitu juga dengan kerjasama kelautan dan perikanan antara pemda Jabar dengan pemda Cholanamdo memungkinkan terjadinya alih teknologi dari propinsi Republik Korea tersebut kepada pemda dan nelayan Jabar. Manfaat lain bagi masyarakat yaitu adanya peningkatan kemampuan para nelayan yang menjadi sasaran objek kerjasama dalam melakukan penangkapan ikan yang berdampak pada peningkatan kesejahteraan mereka.

\section{Kesimpulan}

Dari penjelasan beberapa aspek di atas dapat disimpulkan bahwa bagi pemda Jabar, kerjasama dengan pemda Cholanamdo dalam bidang kelautan dan perikanan tersebut relatif efektif. Efektifitas ini dapat dilihat dari terlaksananya poin-poin kerjasama yang telah disepakati oleh kedua pihak. Selain dengan keberadaan MoU dan bentuk kerjasama yang lebih spesifik yang tertuang dalam MoU tersebut, adanya mutual trust antara kedua belah pihak memberikan andil dalam keberhasilan kerjasama. Tentu efektifitas tersebut tidak lepas dari komitmen pemda Jabar dan dukungan dari pemerintah pusat melalui beberapa kementerian terkait.

\section{Referensi}

Kementerian Luar Negeri Republik Indonesia. (2012). Panduan Umum; Tata Cara Hubungan dan Kerjasama Luar Negeri oleh Pemerintah Daerah, Revisi Tahun 2006.

Luerdi, L. (2014). Kerjasama Luar Negeri di Era Otonomi Daerah (Peran Pemda dan Mekanisme Memulai Kerjasama).

Thontowi, J. (2009). Kewenangan Daerah Dalam Melaksanakan Hubungan Luar Negeri (Studi Kasus di Propinsi Jawa Barat dan DIY). Jurnal Hukum, 16(2), 154.

Windiani, R. (2011). Hubungan Luar Negeri Indonesia Era Otonomi Daerah. Studi Evaluasi Hubungan Sister Province (Provinsi Kembar) Jawa Tengah dengan Negara Bagian Queensland Australia Periode Tahun 2000- 2007. Politika, 2(1), 76-98. https://ejournal.undip.ac.id/index.php/politika/article/view/4934 